\title{
Widening the Antimafia net: child protection and the socio-cultural transmission of
}

\section{mafia behaviours in Calabria}

\begin{abstract}
This paper explores proceedings by the Youth Tribunal of Reggio Calabria, Southern Italy, aimed at the protection of children in families where one or both parents are investigated for mafia offences. The findings show that preventing the transmission of mafia ('ndrangheta) culture in the local context has become an essential part of child protection measures. This paper will argue that when discussing child protection in criminal families, it is necessary a) to question the nature of the bonds of these families with the socio-cultural context; and, b) to concretely assess the way this context wishes to affect the family's criminality.
\end{abstract}

Keywords: mafia; criminal families; organised crime; Italy; youth justice; cultural transmission; child welfare 


\section{Introduction}

'Ndrangheta is the collective name given to mafia clans in the Calabrian region at the toe of Italy. Antimafia prosecutors in Italy claim that the "ndrangheta is the most powerful mafia both in Italy and also abroad (DNA, 2017). Indeed most contemporary literature on the 'ndrangheta highlights its global reach, its mobility and its capacity to penetrate and dominate various legal and illegal markets nationally and transnationally (Sergi and Lavorgna, 2016). This paper examines the ways in which the Youth Tribunal in Reggio Calabria - and in Reggio Calabria only in the whole of Italy - is attempting to break mafia power locally, by affecting the way mafia culture and behaviours are transmitted and learned in mafia families. Controversially this involves removing children from their families and, in some cases, sending them to live in other regions of Italy in foster care.

The paper draws on a research project, which analysed a sample of case files (involving 18 proceedings) from the Youth Tribunal (hereinafter the Tribunal). The files contain witness statements and transcripts of intercepted conversations - from the public prosecutors within the District Antimafia Prosecutor Office (DDA) of Reggio Calabria. They also contain the final orders, issued by the Tribunal in each of these cases, to revoke paternity rights and separate children from their families when one or both parents had been investigated or on trial for mafia offences.

Access to the files was granted by the DDA in Reggio Calabria, and all details of the cases have been anonymised. For the purposes of this paper, a "child" is a "minor" (below 18 years old); specifically, the Youth Tribunal in Italy handles cases of minors within civil law (i.e. family law), administrative law (i.e. anti-social behaviour complaints, or prostitution of a minor and/or other victimisation), and criminal law (for 14-18-year old who commit 
crimes). The cases reviewed in the paper primarily fall into the first competence of the Tribunal, and at times the third.

Whilst the sample size on which the paper is based is relatively small, the practice of the Tribunal in attempting to break mafia power is relatively new, as at the time of writing there have only been around 40 (finalised) cases in total with some more in the making. However these cases raise issues of wider significance for youth justice scholarship: namely how best to afford protection to children in the context of organised crime families especially mafia-type organised crime, family criminality and locally-based criminogenic cultures. There is a growing body of international research literature which has criticised judicial interventions aimed at so-called 'child saving' as having iatrogenic effects (Muncie \& Goldson, 2012; Monahan et al., 2015). However I will argue that the Tribunal cases highlight ways in which mafia values have been culturally transmitted from generation to generation, and that the decisions of the Tribunal to remove children from the area and separate them from their families of origin, find some justification as a long-term preventative measure to combat the reproduction and damaging effects of mafia-type organised crime.

The paper will first present theoretical considerations relevant to discussing 'ndrangheta families and children from a perspective linked to both mafia studies and youth delinquency; second, it will present key findings from the analysis of case files, highlighting the ways in which the Tribunal has dealt with the difficult balance between child welfare and protection.

\section{The 'ndrangheta and Calabria}


The "ndrangheta was classified as "mafia" for the purposes of article 416-bis (Italian mafia offence) of the Penal Code only in $2010^{1}$, even though its origins are much older and date back at least to the unification of Italy in 1861 (Ciconte, 2011). The Calabrian mafia today is object of much debate in contemporary scholarly work; in particular its criminal activities, especially drugs, in Italy and abroad (Calderoni, 2012; Calderoni and Caneppele, 2009; Lavorgna, 2015a; Lavorgna, 2015b), and its movement and expansion worldwide (Calderoni et al., 2016; Varese, 2011; Sergi, 2018). Indeed, the 'ndrangheta is now considered to be the principal Italian mafia worldwide (Sergi and Lavorgna, 2016). This particular study, however, provided the opportunity to explore its impact on family life and child development in its place of origin, the Southern Italian region of Calabria.

In Calabria, the term 'ndrangheta means two different things. First, the "ndrangheta is a criminal organisation rooted in the city of Reggio Calabria and its hinterland. One of the most important investigations of the past decades, code-named Operation Crimine ${ }^{2}$, in 2010 confirmed that, especially in the Southern part of Calabria, the "ndrangheta is extensive, made-up of different clans ('ndrine), organised around alliances of surnames and families bonded by blood or marriage (Pignatone and Prestipino, 2013; Paoli, 2003). It is a "mafia"type organised crime group because it bases its power and its criminal activities on alliances aimed at acquiring both economic and political privileges through intimidation and exploitation of culture (Dalla Chiesa, 2010; Sciarrone, 2014a). In a territory as diverse and fragmented as Calabria (Sergi, 1993), however, we could indeed talk about different 'ndranghete (plural) as the other provinces in the Calabrian region, are definitely not free from mafia behaviour based on family alliances. These shared features represent the second meaning of the word 'ndrangheta: a collective indication of a set of behaviours, a "way of

\footnotetext{
${ }^{1}$ With Law Decree 50/2010

${ }^{2}$ Operation Crimine, Procura della Repubblica presso la Corte d'Appello di Reggio Calabria, No. 1389/08 R.G.R.N DDA, No. 3655/11 R.G. GIP/GUP, No. 106/12 Sentence
} 
being" and "doing" mafia in Calabria, which can be referred to as "ndranghetism (Sergi and Lavorgna, 2016). No mafia clan is a separate and marginal entity, but they are organic to their communities (Sergi, 2015). Some cultural elements of Calabrian society can, and have been, absorbed into the mafia culture and vice versa. For example, amongst Calabrians there has always been recognition of what constitutes "ndranghetist behaviour and how it is manifested (Piselli and Arrighi, 1985). This is very well portrayed in the verb 'ndranghitijàri, which in Calabrian dialect means to publicly adopt a 'cocky' behaviour, the superior attitude typical of a (male) mafia affiliate, who is respected and feared, and who voices a strong disregard for authorities and formal control. This attitude is part of the "ndranghetist behaviour, which everyone in the community - affiliates and non-affiliates - can instinctively recognise.

This does not mean that the Calabrian culture is ontologically criminogenic. Rather, all Calabrians grow to understand (but not necessarily always agree upon) certain social and cultural codes and values - which are taken to be "common sense" (Christopher et al., 2014). These meanings form "webs of significance" in the way people communicate, do things together, explore and foster relationships with one another, so that it is not necessary to question behaviours all the time: but behaviours, good or bad, are nevertheless recognised $a$ priori by members of the same communities (Geertz, 1973).

For example, Calabrian culture historically places considerable importance on family bonds and on the authoritative role of fathers, in line with a general tendency of Southern cultures (Tarsia, 2015). Mafia families, notwithstanding their criminal nature, are also Calabrian families. Not only the "ndrangheta basic unit is the family (the "ndrina that expands through family bonds of marriage and blood), but also matters related to each 'ndrina are certainly dealt with through the recognised and uncontested authority of the pater familias who often is a mafia boss as well (Paoli, 1994). 


\section{Mafia values and cultural transmission}

In line with their culture of reference and with their characterisation as mafia groups, 'ndrangheta families are characterised by a family-based, authoritative and dogmatic mentality, and the awareness that only what is near and close is of value (Pignatone and Prestipino, 2013; Ciconte, 2011). Mafia culture is based on an order and system of values, which is transmitted in what Schermi (2015: 257) calls a "black pedagogy", a "twisted" form of education. Children's behaviour, especially young men's behaviour, in 'ndrangheta families has not been object of much specialist scholarly enquiry. However, as Mostrobuoni and Patacchini (2010: 5) remind us, in all mafia families "children might be important, both because of strategic endogamy, and because male descendants represent trusted potential associates". Influence and trust, especially in "ndrangheta clans, are established and preserved through family bonds; family surnames are already an indication of the family status among other families. Both sons and daughters, therefore, play a role in preserving a 'ndrangheta family's surname and its influence (Pignatone and Prestipino, 2013), but in different ways: the sons will carry on the family businesses and lead the clan's activities and the daughters will forge and strengthen alliances through marriage.

The 'black pedagogy' referred to above has, arguably, much in common with classical theories of social learning, such as differential association theory, which postulates that criminal behaviour is learned through interaction and communication within intimate groups, and that a person becomes delinquent because he/she receives more definitions in favour of violation of the law than definitions in favour of law-abiding behaviours (Sutherland, 1947). 
Additionally, groups engage with the environment and interact among each other, to share and learn cultures of delinquency (Cloward and Ohlin, 1960).

There is also an obvious link with scholarly literature, which looks at delinquent sons and daughters of delinquent parents and explores the extent to which "delinquency runs in the family" (Wilson, 1987; Farrington et al., 1975). An important finding from this literature is that the gender of the delinquent parent matters. Criminal fathers determine children's delinquency more than criminal mothers (Farrington et al., 2001; Demuth and Brown, 2004), with incarcerated fathers adding to the weight of "intergenerational continuities in exposure to multiple risks" (Farrington et al., 2001: 593). Arguably, this applies even more to mafiatype families, which are considered traditional systems of power fundamentally excluding women from official roles (Lupo, 2011) and primarily based on concepts of honour, virility, and violence as manifestation of manhood (Zaitchik and Mosher, 1993; Travaglino et al., 2016). In all mafia families the prominent role is the one of the father, both for running the family as well as the (mafia) family business (Mastrobuoni and Patacchini, 2010). Even though women are not given official roles in running the family business, they at times, take on (unofficial) leading roles on absence of their husbands (Ingrascì, 2007).

Mothers, however, have a crucial role to play in the cultural transmission and preservation of mafia values. As demonstrated by Ingrasci (2007: 51) in her analysis of interviews with 'ndrangheta women, all mafia mothers are educators: they educate to revenge, they "instil" - "inculcate" - mafia values (such as the code of silence to protect family members), they are responsible for "the act of rooting a set of values that later become normality and as such help the children to carry out criminal activities". Mothers, whether or not they are willingly or unwillingly supporting the family's criminal activities, are protective of their children (Ingrascì, 2011; Dino, 2007). This means teaching them: how 
to behave in a mafia family to avoid conflicts with other family members; what is expected of them; how to cultivate their philotimia ${ }^{3}$; and the rules of a "career" within the mafia family.

In Calabria, the protection of children has often been a core concern for law enforcement. Research has shown how "in some towns in Calabria marked by bloody feuds during the 1970s and 1980s, the entire civil context is compromised" and this "carries lasting consequences for new generations" (Siebert, 2007: 29). Notably, in 1975 when two children, aged 11 and 8, were killed during a mafia feud, the Youth Tribunal in Reggio Calabria ordered, for the first time and with considerable public support, to "send away" the children for their own protection in order to save them from a certain mafia destiny (Sergi, 1991a; Sergi, 1991b). This exceptional measure, however, was, at the time, not part of a systemic application of either criminal or family laws. Since then, Italian authorities have developed various direct and indirect Antimafia measures and legal provisions to secure the punishment of adults as well as the protection of children in mafia contexts until the most recent development object of this analysis. And it is to the emergent jurisprudence from the Youth Tribunal that the next section of the article turns.

\section{Revoking Parental Authority in mafia families in Calabria: the legal basis}

There are a number of ways in which Italian law enables the separation of a minor from his/her "inadequate" parents should they not meet the legal requirement of providing the child with appropriate care and education. Parental duties to support children's welfare, personally and financially, are set out in the Constitution (article 30) in line with international

\footnotetext{
${ }^{3}$ Philotimia is the love of honour. As a concept, it dominated the matrix of values in the GrecoRoman world. In particular the males of a society are tasked with obtaining, maintaining and sustaining the honour of their families and their families' name by doing what is expected of him, by having philotimia.
} 
conventions for children protection. On occasions the courts have used article 34 of the Italian Penal Code (loss/withdrawal of parental authority) as an ancillary punishment. (NB such procedures are meant as additional punishment for the parent rather than protection measure for the child (Todini, 2015)).

The proceedings analysed in this study, however, are not criminal law measures; they are based on articles 330 and 333 of the Civil Code, family law section. Article 330 provides for the removal of the child from home with subsequent loss of parental authority in cases of gross negligence. Article 333 allows a unilateral decision by the Tribunal to separate the child from his/her home and parents when the parents' conduct and the family context are prejudicial to the child's education and wellbeing. The application of this provision must be based on an evaluation of the child's delinquent or risky behaviour as well as the degree of parental negligence.

In March 2015 a judicial protocol ${ }^{4}$ was circulated amongst all youth and adult courts in the Reggio Calabria district to resolve competence issues and facilitate the sharing of information in cases involving children of individuals under investigation or charged by the District Antimafia Prosecutors (DDA) in Reggio Calabria. In fact, as the purpose of the DDA is to conduct investigations into mafia clans and mafia activities over time, they hold a great deal of information and intelligence on these families and therefore on the children themselves in addition to what relates to specific charges and trial procedures. The March

\footnotetext{
${ }^{4}$ Protocollo d'Intesa tra gli Uffici Giudiziari del Distretto della Corte d'Appello di Reggio Calabria per concordare modalità operative, di coordinamento e comunicazione nei casi di: 1) procedimenti relative ad abusi sessuali o matrattamenti in pregiudizio dei minori; 2) procedimenti penali relative a reati commessi in concorso da soggetti minorenni e maggiorenni; 3) procedimenti civili a tutela di minori figli di soggetti indagati/imputati/condannati per i reati di cui all'articolo 51 comma ter bis c.p.p. e altro; 4) procedimenti civili relative a minori e a nuclei familiari sottoposti a misure di protezione (Joint Protocol among Judicial Offices in the District of the Court of Appeal of Reggio Calabria to agree on operational cooperation and communication in cases of: 1) proceedings related to sexual abuses against minors; 2) proceedings related to crimes committed by minors together with adults; 3) civil proceedings to protect minors sons or daughters of individuals under investigation/charged/convicted within article 51.3 of the code of criminal procedure [Antimafia proceedings); 4) civil proceedings for minors in families subjected to protection measures)
} 
protocol explicitly recognised that Antimafia operations often involve, directly or indirectly, children: children who either committed delinquent acts or supported the adults in the family, or who were victims of mafia violence. This protocol followed an earlier agreement signed by all local courts in March 2013 which stated that the very structure of the "ndrangheta called for more joined-up intervention ${ }^{5}$ :

"The family-centred structure of criminal groups in the territory of the District of the Courts of Reggio Calabria and the more and more frequent involvement of minors in delinquent activities make it a pressing matter to intervene in coordination against certain 'families' with civil law procedures in youth justice in parallel with criminal law measures".

The president of the Youth Tribunal, Judge Roberto Di Bella - also a Calabrian - has been the main pioneer of these procedures; these procedures have been ratified regionally in a project called "Liberi di Scegliere" (Free to Choose) in 2012. This was an educational project, involving other Antimafia NGOs in the territory as well, that wished to start a support network and an intervention from the Tribunal in families of mafia ("ndrangheta) to make sure the children of these families do not follow the same path of their parents by abiding to mafia culture. The stated purpose of the Youth Tribunal in these procedures is to protect the "psychosocial equilibrium" of children "on the basis that the behaviours promoted in [mafia-type] criminal organisations are incompatible with the educational function that directs parental powers and duties" ${ }^{\prime}$. As other authorities joined the cause,

\footnotetext{
${ }^{5}$ Ibid., page 13

${ }^{6}$ Tribunale per i minorenni di Reggio Calabria, decree of 17.05.2016
} 
various other decrees were issued between 2015 and $2016^{7}$, outlining how the Youth Tribunal could work to support the protection of children from mafia families, with a view, in the future, to validating such practices in other Youth Tribunals across the country. In February $2018^{8}$ the protocol has been ratified by the Presidency of the Councils of Ministers, the National Antiamafia Prosecutors Directorate (DNA) and the Italian Episcopal Conference, in what starts to be - very symbolically - a united front and a network of contacts and agencies all against mafia power in the whole country.

\section{Youth Tribunal discourse on mafia culture: key findings}

Analysis of the case files highlights the ways in which the Tribunal, in practice, makes an explicit connection between the child's risk of deviance and parental failures to educate the child. The Tribunal's discourse is often based on, and corroborated by, judgements on the nature of mafia power in the area formed beforehand, thanks to years of observations and work in the territory. Looking across the files, there is strong evidence that "meanings" and "judgements" are shared by the authorities of the same territory and relate to conceptualisations of mafia (sub)culture, how it is manifested, nourished and transmitted in the local context of Calabrian culture. Each case is carefully examined individually, but decision-making follows three key steps, which are considered necessary to standardise the practice across different cases.

1. Assessment of behaviours within families (including fathers, mothers and children).

This relates to the general condition of the family, including parents, children, and

\footnotetext{
${ }^{7}$ See for example: Tribunale per i minorenni di Reggio Calabria, decree 29.09.2015; decree 08.03.2016; decree 26.04.2016; decree 17 maggio 2016; President Roberto Di Bella

8 See press release of the Italian Government on the $2^{\text {nd }}$ of February 2018 at http://www.governo.it/media/progetto-liberi-di-scegliere/8896
} 
other family members. In all the proceedings analysed, the figure of the father represented the main concern: parental authority, in the cases assessed, is always revoked to the father when he is a known mafia member or under investigation/indictment/charge for mafia-related crimes. On the other hand, mothers were often given "second chances"; the Tribunal was reluctant to revoke also the mother's parental authority even when they were under indictment/charge for mafiarelated crimes. When children were in direct and continuous contact with other family members, such as grandparents, the Tribunal evaluated the behaviour and conduct of extended family members as well.

2. Assessment of the transmission of mafia values. This related to the actual sharing/transmitting of mafia behaviours within the family, and also was found to be highly gendered. In the cases assessed, male children were reported to conform to the stereotyped masculine behaviour expected of them in mafia environments, often exhibiting violent and aggressive behaviours. This required an extra effort on the part of the Tribunal to understand the mechanisms of indirect victimisation to which the young men were subjected. By contrast, female children were portrayed in the files as eager to escape their destiny or highly victimised. In brief, the cases suggest that the idiomatic expression "like father like son" is at the basis of the judgement of the Tribunal, whereas things are more nuanced between mothers and sons or daughters.

3. Assessment of the best option(s) for the children. This included the revocation of parental authority (which happened only for the fathers), the separation of the child from the family at large, education programmes, removal from the region, foster care and health/psychological support.

Each stage of decision-making is explored in more detail below: 
Assessment of behaviours within families (including fathers, mothers and children)

In one of the case files analysed ${ }^{9}$ the Tribunal explicitly commented on how the conduct of parents in mafia families "are not only relevant for criminal law, but they represent a clear disparagement of the most elementary rules of education and assistance of a minor, as well as being concrete violations of the duties imposed onto parents by the law". In the judgements of tribunal analysed, the "successful" transmission of mafia culture was always linked to the figure of the father, his influence and his prestige as a mafia member. This was one of the main reasons why the proceedings always resulted in the legal separation of children from their father. The role of mothers was often safeguarded in recognition of the different roles and behaviours of women in mafia families and in light of the value, which the Tribunal placed on the bond between mothers and children. Even in the few cases where a mother temporarily lost her parental authority - or when the child was separated from the father and the parents were still together, or he/she was sent away from the family home, the mother was always allowed to maintain contact with her child: in other words she was given a chance of "redemption" as a mother. It should be emphasised, that the Tribunal appeared to judge each parent separately and also considered the potential influence of other family members on the education of children.

In the case of Dario $(13)^{10}$, for example, both his parents were arrested and charged for drugs and arms possession ${ }^{11}$. His father was described in the case file as a man of "awful moral and civil reputation (...) clearly impermeable to any attempt to rehabilitation and unable of critical revision of his own actions". His mother was perceived to be "similarly

\footnotetext{
${ }^{9}$ Tribunale per i Minorenni di Reggio Calabria, Proc. No. 2/2012

${ }^{10}$ Tribunale per i minorenni di Reggio Calabria, Proc. no. 212/14 R.G. Vol. Giur. N.907

${ }^{11}$ Proc. Penale N. 6363/13 Procura della Repubblica press la Corte d'appello di Reggio Calabria
} 
incapable of containing her son and his repeated manifestations of irregular conduct, which she minimises instead". The Tribunal maintained that the parents' behaviour was prejudicial to the minor and amounted to abuse as they "induce him to commit offences". As reported in the case file, Dario was aggressive to schoolmates, threatened teachers, vandalised school property, left school unauthorised, used vulgar and offensive language towards school staff, roamed daily in the streets of the village, he was even cruel towards animals ("he threw a small dog from the outside balcony of the main church, six metres tall”). The child's behaviour for the Tribunal is linked to poor parental supervision and connected to inadequate education. Dario's father had also sent a letter threatening revenge on the prosecutors and the judges, which stated: “my life has been spent in jail, so I don't have any concern about consequences, but we all have children...my ruin will come with someone else's ruin". $\mathrm{He}$ had also sent a letter to Dario promising that "we will see who this judge is and I swear to you that you will be home soon, whatever it takes". The Tribunal considered these letters to be evidence of mafia-type behaviour: an intimidating behaviour typically against the authority, blaming the authorities for the "persecution" against the family, twisting the meaning of justice and promising revenge. However, Dario's mother was assessed rather differently: by not showing “...any hostility towards the actions taken by the Tribunal, which [...] makes us hope for her undertaking a path of self-critique”. Notwithstanding her criminal history, non-hostility is already a good enough reason to re-evaluate the mother's behaviour and distance it from the father's.

The separate judgements on parents occurred also in cases where there was no evidence of delinquent behaviour on the part of the children. As illustration I use the case of Gino and Rita. They were brother and sister aged respectively 1 and 2 years old, when the Tribunal dealt with their case jointly ${ }^{12}$. Their father was a very well known mafia boss in the

\footnotetext{
${ }^{12}$ Tribunale per i Minorenni di Reggio Calabria, Proc. No. 58/2008, vol. giur. 786
} 
city, convicted for various serious crimes and he was also a fugitive. In this peculiar case, the Tribunal assessed the "actual, concrete danger that the father's personality - characterised by the crimes committed - can determine the absorption of a mafia culture in the future". The Tribunal had the difficult task to evaluate how much the father's criminal career and his reputation could "facilitate the subjection of the children to the logics of preservation and predominance of mafia power or, more simply, the negative homologation to deviant cultural models, against the rules of the social contract". In this scenario, the role of the children's mother was crucial. Not only had she never participated in criminal activities, but also her family of origin historically had never been involved in mafia business. Thus, while the children's mother and her family had been solely responsible for the education and the upbringing of the children (because the father had been a fugitive for years), by revoking the patria potestas to the father, the Tribunal aimed to guarantee "that the children in the future will not be subjected to the father's influence and his deviant cultural models".

Indeed, the engagement of fathers in mafia-related behaviour and activity was often sufficient to consider them unfit for their role as educators by default, even when they were not fully or always present for their children, as demonstrated in the following extract (involving a very young non-delinquent child and father on the $\operatorname{run}^{13}$ ): "the attitude of the man, his disregard for justice even after conviction, and his fleeing away, is clearly a selfish act to avoid custody and as such has essentially amounted to his absence as a father; this attitude has had serious repercussions for the children and needs to be punished with the loss of paternity rights”.

As noted, the decision-making in the Tribunal also touched upon other family members beyond the parents. This is arguably linked to the recognised value of an extended family life in Calabria, together with a well-entrenched knowledge of the mafia context of

${ }^{13}$ Tribunale per i Minorenni di Reggio Calabria, Proc. No. 8/2008 
which these families are a part. Emblematic is the case of a woman, Norma, who had left her three children with her own parents upon entering a witness protection programme ${ }^{14}$. Because of her decision to cooperate with the authorities, the family disowned her, which - allegedly - drove her to suicide [the case was afterwards ruled as murder]. In this case, the Tribunal considered the grandparents unfit to educate Norma's children on the basis of their behaviour towards Norma, their own daughter. Not only had they used the children to attempt to lure Norma back to their house, but also the file also indicated that the grandparents had told the children that their mother was a traitor, had besmirched the family's honour and thus could not be forgiven for what she had done - namely offering evidence to the prosecutors. The Tribunal stated that the grandmother had actively "used the children as a commodity" to trick her daughter to come back. The grandmother's attitude towards her daughter was presented as fundamentally rooted in twisted mafia values. A transcript of a phone interception in the file reports the grandmother's words to Norma: “you are confused because of them [the prosecutors] and because you are in love [with another man other than your husband]. Come home, we will fix this, she [the youngest daughter] is confused as well by all this, you come home".

Assessment of the transmission of mafia culture

The second step in decision-making, the assessment of the transmission of mafia culture, is the most controversial of the whole procedure, and the one that is less likely to be understood outside of the territory of reference. It is my view that without a clear understanding of the exact nature and impact of mafia behaviours, it is very likely that such decision-making procedures will be considered unreasonable from a child welfare point of

\footnotetext{
${ }^{14}$ Operazione Onda 2, Proc. no. 3469/11 R.G.N.R + Proc. no. 1959/11 R.G. G.I.P., Tribunale di Palmi (Reggio Calabria)
} 
view. The existing tension, in these proceedings - across competing aims of child protection, crime prevention and punishment - can only be resolved by understanding why the need to break the transmission of mafia culture prevails as long-term prevention strategy. In other words, the Tribunal justifies the separation of children and fathers and/or the removal of children from their family homes, because of the specific nature, scope and pervasiveness of mafia culture in Calabria, and especially in the city of Reggio Calabria. Child welfare and protection in certain Calabrian families can only be guaranteed by breaking mafia culture and its intergenerational transmission first. This intent is demonstrated by the fact that (in the cases analysed) it was often the mothers themselves who were seeking the support of the Tribunal in an attempt to "save" their children from the future that awaited them: protecting the children means breaking their mafia destiny.

The peculiarity of mafia crimes lies with the roots of mafias as social phenomena, their links with territories and their conceptualisation as a set of recognised and shared behaviours within a given culture (Paoli, 2014). The starting point for the Youth Tribunal when addressing the best way to deal with children in mafia families was the consideration that mafia behaviours were indeed embedded in the territory of Calabria, as shown in the following extract from the case files ${ }^{15}$ : "the cultural model based on the values and rules of mafia associations permeates significant parts of this territory. It generates deviant models of behaviours because mafia associations are based on abuse and practices of violence and intimidation; they can even sacrifice the highest value of life". According to the Tribunal, in a mafia family, children "normalise" mafia values and behaviours when committing crimes at very young ages or when they see others committing crimes. Children acquire mafia behaviours and values and justify their actions through family endorsements.

${ }^{15}$ Tribunale per i Minorenni di Reggio Calabria, Proc. No. 58/2008, vol. giur. 786 
The case of Lara (13) and Aldo (14) ${ }^{16}$, brother and sister, is a good example, and also shows how traditional gender roles play a part in the normalisation and acquisition of mafia values and codes of conduct. In this case, both parents were in prison following Antimafia Operation "Cosa Mia" ${ }^{17}$, which dismantled one of the most prolific clans in the region. Aldo had also been charged for mafia association, as a minor; he would face trial by the time he reached 16 years of age. Lara too was formally under investigation ${ }^{18}$ for her (unwilling) role in concealing sums of money, proceeds of extortion, on behalf of her parents. Reflecting youth crime literature, the incarceration of both parents has different effects on sons and daughters (Bijleveldc et al., 2016). Lara firmly declared to the prosecutors how she considered herself "alien to the family's activities" and she had repeatedly tried to "stay away from the extortion racket as it is not interesting”. Notwithstanding her declared distance from her family and her "hope to leave Calabria in the future", the Tribunal produced evidence that the risk of deviance for Lara was still high; she was "worryingly subjected and under the pressure of her family's reputation". Her family had "a crucial position in the organised crime scenario of the town of reference, no-one could effectively provide for her", which might lead to further deviance. Lara also appeared terrified by the possibility of retaliation if she "lets down" the family's expectations. She declared: "I shouldn't talk. They will make me pay for it”. In contrast to his sister, the Tribunal assessed Aldo as showing "delinquent behaviour, by conducting a very chaotic life and by avoiding any form of care and dismissing any form of education; he engages in confrontational and at times aggressive conducts, he cultivates unhealthy friendships, he asks for money without any justifiable reason, he comes home late at night without calling first". An interception of one of Aldo's aunt phone calls, (she was also charged with mafia association), worryingly

\footnotetext{
${ }^{16}$ Tribunale per i Minorenni di Reggio Calabria, Proc. No. 335/10 R.G. Vol. giur. No. 2100

${ }^{17}$ Operazione Cosa Mia 1 \& 2, No 4508/06 R.G.N.R.-D.D.A.; No. 107/09 O.C.C.; No. 1/10/O.C.C., Reggio Calabria.

${ }^{18}$ Proc. No. 262/2013 R.G.N.R. Reggio Calabria
} 
revealed how she was "certain that Aldo will give great satisfaction to the family"19. The Tribunal, therefore, feared the "negative radicalisation of damaging life choices", made worse by the family's overall "logic of abuse and social parasitism that ... certainly and diffusely conditioned and limited him, by also promoting engagement in certain (criminal) activities". The Tribunal also commented on how Aldo was "acting as it is expected of him", at the point of also "antagonising his sister", becoming controlling and even violent towards her, when she seemed unwilling to respect the family's rules and values. Aldo did not seem to question the family values; they simply were accepted. This accords with the Tribunal's assessment of Dario's case ${ }^{20}$ (mentioned earlier): that the boy considered the engagement with his father's business - helping his father hiding guns and other weapons -as a father-son activity, something that was "time shared with his father, part of their special relationship".

In the cases analysed, the older the child the more certain behaviours appear normalised. For example one of the case files ${ }^{21}$ notes a recorded conversation between a 16year-old boy and his father (in prison) about the suicide of the boy's mother (Norma, mentioned above). Even when questioning whether his mother's suicide might have been instigated by the behaviour of family members, the boy was perceived to be still justifying the family, blaming his mother, and disrespecting the work of the authorities - the essential "enemies" of mafia culture. The file contains evidence that the boy was worried about what his mother might have said to the police, perceiving this as a shame and a burden on the family as a whole. He considered: "granddad was certainly acting jealous and aggressive... certainly it was also the Carabinieri's [local police force] fault, but mostly it was his fault”. But then he adds, talking to his father directly: "What can I say against him [his granddad] anyway? He takes care of me! And what happened just happened...she [mum] wanted to kill

\footnotetext{
${ }^{19}$ Operazione Cosa Mia $1 \&$ 2, No 4508/06 R.G.N.R.-D.D.A.; No. 2815/07/ R.G.I.P. D.D.A.; No. 107/09 O.C.C.; No. 1/10/O.C.C., Reggio Calabria, page 585

${ }^{20}$ Tribunale per i minorenni di Reggio Calabria, procedimento n. 212/14 R.G. Vol. Giur. N.907

${ }^{21}$ Operazione Onda 2, Proc. no. 3469/11 R.G.N.R + Proc. no. 1959/11 R.G. G.I.P., Tribunale di Palmi (Reggio Calabria)
} 
herself, she did it on her own. And now they [the authorities] say it's on us? They want to make it look like it's on us!" The boy, very worried, asked his father, how he could deal with the shame of what happened: "Will the newspapers say that she cooperated? That she became a "pentita" [someone who turned state's witness]? Did she go to the police? What should I say to everyone, at school?”.

As hinted before, these cases call for further investigation of the relationship between mafia families and the cultural elements of the territory, Calabria. It could be argued that because of the shared behaviours and values between the Calabrian culture and the Calabrian mafia, the transmission of delinquent mafia values is a substantial risk. For example, mafia culture promotes social acceptance and prestige in the community, rather than isolation, and it encourages accumulation of wealth and power in the logic of usurpation of others through the power coming from the acquired social status in the community. The importance of recognition of a local social status is a value of Calabrian society in itself, a society historically based on social stratification affirmed by prestige and deference (Silverman, 1966). The mafia version of this value allows for wealth, power and prestige to be accumulated through illegal means and deviant behaviours. Mafia behaviours manifest through the hubris of individuals and their families and more specifically men and fathers still at the apex of mafia families. In the work of the Tribunal with children of mafia families in Calabria these types of 'ndranghetist behaviours are portrayed to be systematic, deeply rooted, consolidated and recognisable in local culture at the point that they are expected by those authorities who know the context and work in the territory. 
Moving on to the third step in decision-making, the research shows that in assessing the best options for children, the Tribunal's main objective remains children protection. However, the Tribunal believed that mafia power in the local context hinders the wellbeing of everyone, especially children, by trapping them in a scripted present and future. Therefore, the evidence suggests, in order to ensure long-term improvements of the overall conditions of the local youth, the transmission and diffusion of mafia culture needs to be reduced. The noxious environment of mafia families, which enabled the normalisation of children's deviance, was deemed to be the most problematic factor for their long-term protection and wellbeing as functional law abiding citizens.

When deciding the appropriate protection measures, therefore, the intention of the Tribunal was twofold. Firstly there was the need to ensure the physical and psychological wellbeing of the child: the Tribunal allocated psychological and health support to every child and also, in order to minimise possible trauma, the authorities attempted to save at least the maternal relationship. Secondly there was the need to restore social and civic skills - to counter the already absorbed mafia culture - through appropriate education. According to the Tribunal, this could not be done in Calabria.

Indeed, in addition to the separation of children from their families, the case files indicate that the Tribunal often considered placing the children out of the region. In contrast with literature that found that mafia culture spread beyond its regional territories of origin because of displacement of mafia families elsewhere (Sciarrone, 2014b; Varese, 2005), and the risks that children might perceive separation as a punishment or be emotionally harmed by it (Muncie and Goldson, 2012), the Tribunal encouraged this practice in the name of children protection. Sending children to facilities or families to the North or the Centre of Italy is supposed to cut the environmental bond with mafia culture and to offer the children the possibility of growing up to a different life. This measure is indeed drastic but, as the 
Tribunal put $\mathrm{it}^{22}$, it is necessary to allow the minor to "critically revisit the non-values learned in the territorial context of reference and acquire sufficient autonomy and self-esteem [...] far from logics of usurpation and social parasitism”. Crucially, making them leave Calabria was also considered to be another way of protecting the children from repercussions, vengeance, and prolonged, unhealthy, contacts with their immediate and extended family. In Lara's case ${ }^{23}$ the Tribunal found that "this solution appears to be the only feasible one to avoid retaliation, to save the girl from an unavoidable destiny and at the same time to allow her to experience different cultural, emotional, psychological contexts and an alternative way of living different from the deleterious one of origin, hoping that she can free herself from parental conditioning”.

However, apparently wary of the seriousness of this procedure, there is evidence that Tribunal still attempted other routes when considered safe enough. In one of the cases analysed $^{24}$, the Tribunal chose to assign two sisters to their grandparents in consideration of the fact that sending them away "would not be feasible without creating ulterior worries, conflicts and tensions for the girls" while introducing them to the foster system "would not be adequate either because - apart from causing ulterior suffering to the girl - it might also be misunderstood as a further penalisation and this would not be functional to the psychological evolution of the two minors". The grandparents therefore, were considered the best option, notwithstanding their previous involvement with some mafia activity.

In addition, the Tribunal also enrolled children in specific education programmes particularly aimed at teaching legality and civic duties. While the revocation of parental authority might be temporary and parental rights might be reinstated in the future, education was viewed as the long-term investment for the wellbeing of these children, especially in

\footnotetext{
${ }^{22}$ Tribunale per i Minorenni di Reggio Calabria, Proc. No. 335/10 R.G. Vol. giur. No. 1589

${ }^{23}$ Tribunale per i Minorenni di Reggio Calabria, Proc. No. 335/10 R.G. Vol. giur. No. 2100

${ }^{24}$ Tribunale per i Minorenni di Reggio Calabria Proc. n. 221/13 R.V.G., page 6
} 
consideration of the fact that education to mafia culture is the primary problem the Tribunal seeks to fix. In order to support the educational focus of its provisions, the Tribunal's discourse drew inspiration from the United Nations Convention on the Rights of the Child 1989, which entitles every child to grow into a family that educates to principles of legality and civility, human solidarity and dignity as well as protecting the child from risks associated to the lack of such social and civic values. As stated in one order ${ }^{25}$ : it is necessary when the family is neglecting educational roles and actually exposes the child to delinquency and deviance "to allow the child to enjoy different educational paths to ensure (s)he has an alternative to what would be a certain future of delinquency".

In the assessment over the best options for the children crucial, again, is the role of mothers. As said before, mothers are often the ones who voluntarily offer their support to the Tribunal or demonstrate a willingness to cooperate with authorities to "save" their children from a mafia future. Even when deciding to send away the child, the Tribunal, therefore, attempted to keep the mother involved, by scheduling regular meetings with the children elsewhere, and to avoid the complete isolation of the minor.

\section{Discussion and Conclusions}

This paper has analysed a small but representative number of cases of a new procedure adopted by the Youth Tribunal of Reggio Calabria in partnership with the District Antimafia Prosecutors in the city. The findings of this paper contribute to discussion within two main perspectives: 1) the qualification of mafia power - and its policing - as local and contextualised set of social and criminal behaviours affecting also family life; and, 2) child

\footnotetext{
${ }^{25}$ Tribunale per i minorenni di Reggio Calabria, procedimento n. 212/14 R.G. Vol. Giur. N.1941
} 
protection as a preventative measure against the diffusion of organised crime and career delinquency. Considering these two points together - as they are interconnected in these proceedings - not only helps to understand the motivations of the Youth Tribunal of Reggio Calabria in these practices, but also can direct new directions for research in the field of youth justice, family delinquency and organised crime.

As for the first point, the particular setting of the Southern Calabrian territory in which these proceedings originate further characterises their significance. In fact, the native context can be considered a mafia-dense territory, where local clans - the 'ndrangheta - base their strength and pervasiveness on a set of social behaviours, which are "twisted", deviant and criminal versions of local families' values and cultural codes (Sergi, 2017). 'Ndrangheta families are indeed Calabrian families - made of individuals born and bred in Calabria. As such they share Calabrian cultural codes in their everyday life, at the point of being able to manipulate them. As previously said, Calabrian cultural codes are not intrinsically 'ndranghetist, but the "ndranghetist cultural codes are also, in a twisted way, Calabrian. The cases analysed for this paper confirm how criminal behaviours in a mafia-dense territory like Calabria become a socially transmitted deviant (sub)culture. This is a crucial point for a final discussion in this paper: the intersection between local culture and systemic criminal behaviour, or in other words, the cultural elements of mafia-type organised crime. It can be argued with part of the literature that the cultural bonds of criminal organisations with their territory of origin create spaces for governance (Varese, 2011) as well as increasing the group's criminal reputation (Von Lampe, 2016; Sergi, 2018). It has already been suggested elsewhere that the knowledge of the socio-cultural elements of a context and territory could support the policing and contrasting of criminal systems seeking power and profits through illicit means; how to do this without producing court bias is the challenge for further sociolegal research in this field. 
Indeed, the Tribunal portray mafia behaviours in Calabria as so endemic to the local territory and culture, that the removal of children from the region becomes an option for child protection: indeed, the transmission of the "ndranghetist (sub)culture and its values is linked both to the territory and to family life. Further research in this field also needs to assess how changes within Calabrian culture and Italian society as a whole - for example the perception of traditional gender roles - are affecting mafia (sub)culture. Indeed, whereas values like masculinity, virility and manhood are traditionally linked to Southern Italian culture (Travaglino et al., 2016), the contextualisation of gender roles and the changing nature of gender as a concept across families and societies worldwide (Lindsey, 2016) might have an impact upon traditional values.

These social changes need to be monitored also in their impact on the courts and the justice system as a whole. Again, a cultural and contextualised approach to mafia power calls for a deep analysis of the 'power' of the courts, especially for child protection. The meaning of 'punishment', 'protection' and 'prevention' in the local child welfare system needs to be further scrutinised to make sure that a cultural and contextualised approach does not become biased and does use cultural knowledge of the territory as an asset and not an obstacle. Even though the Tribunal assesses cases individually, the issues at stake are never limited to just one case, precisely because the end point is not only the protection of children but also the prevention of mafia culture transmission. To fully evaluate the effects of these provisions on children in the long term, it would be desirable to conduct a follow up study on the children subject of these proceedings in the medium term ( 5 to 10 years from now) to assess whether the bonds with the mafia culture have indeed been severed or whether mafia pedagogy has been absorbed despite the measures in these proceedings.

As already noticed, these proceedings need to be critically read from both a youth justice perspective, and a perspective of organised crime prevention. At first sight, the 
interventions in this paper clash with literature that suggests that the removal of a child from home - however 'inadequate' that home is deemed to be - is normally experienced by children as punishment rather than protection and consequently can undermine their wellbeing. The interface between criminal justice and child welfare - what Harris and Webb (1987: 7) referred to as "the meeting place of two otherwise separate worlds" - leads scholars to question the (il)legitimacy and the practical (often iatrogenic) effects of relying on judicial intervention as a form of 'child saving' (Monahan et al., 2015; Muncie \& Goldson, 2012).

It is recognised that relying on civil legislation to address criminal transgressions (and/or vice versa) is deeply problematic both ethically and practically when it comes to children (Ahrens, 2000). In the US, studies have discussed the increased risks of children from the care system crossing over to the criminal justice one (Krinsky, 2010). In the UK the imposition of 'care orders' and the removal of children from their families in criminal (juvenile/youth justice) proceedings have long been debated and contested (Dingwall et al., 2014; Harding, 2014). Research suggests that these court powers frequently produce poor outcomes both in terms of child welfare (causing emotional distress) and juvenile/youth criminality. In general, the complex and contested effects of removing children from families on preventive grounds is well established and commentators have been particularly critical of practices which lead to the objectification of children in order to accuse parents (Featherstone et al., 2014). There have been, however, a few studies that have indeed showed improvement in the quality of life of children who are removed from negligent homes (Davidson-Arad et al., 2003). This might suggest that this debate needs to be contextualised and results might change in cases of multi-generational criminal families, where cultural aspects - for examples when endogamy and religious rituals become part of affiliation and recruitment mechanisms - become part of the collective identity elements of a group, as it is the case of 'ndrangheta families in Calabria. 
The proceedings analysed and the selected case studies presented in this paper demonstrate that the debate around child protection needs to be local, as it is affected by cultural and social contexts. Additionally, measures aimed at child protection can, in turn, affect the culture of origin, and - as in these proceedings - can become part of a prevention strategy aimed at counteract the diffusion and transmission of mafia behaviours and delinquent subculture. By intervening to support the education and the emancipation of the youth of the "ndrangheta in the short and medium term, the Tribunal aims at disrupting mafia power in the territory by hitting, in the long term, one of its main resources: endurance. The longevity of criminal associations, as their reputation, as said, is more often than not linked with the control and osmosis with the socio-cultural and economic traits of the territory of origin (Von Lampe, 2016). Mafia power, in this sense, is the manifestation of a totalising control over a territory: the more pervasive this control is the more criminal power perseveres and the more that power can settle in the political, the economic, the social and the personal spheres of communities (Sergi, 2017).

In conclusion, when discussing child protection in criminal families, it is necessary a) to question the nature of the bonds of these families with the socio-cultural context they are in; and, b) to concretely assess the way this context affects and directs the family's criminality. For certain criminal families, the local socio-cultural context remains in the background and the local context represents only a place to do business or live in. In this scenario, measures of child protection and attempts of saving children from intergenerational transmission of offending have to obviously consider the individual personality of the child within his/her familial relationships and make a judgement on whether the criminal family is also a negligent family (Farrington et al, 2009). In accordance with literature in this field (Dufour et al., 2008), parental and educational negligence do not imply criminal involvement in both parents and children, thus the ways in which of thus separation and removal from 
home might not be the best solution for purposes of child protection and different welfare responses, not based on risk-policies, should be considered (Muncie, 2014).

For other criminal families, like the ones considered in this paper, the socio-cultural context is a qualifier of their behaviour, both criminal and social. The strongest family ties are in and with the local context, the tighter the criminal group becomes, thus consolidating its reputation, longevity and success. This is certainly part of the definition of mafia-type criminal organisations as subcultural groups (Sergi, 2017). In this scenario, measures of child protection and attempts of saving children from intergenerational transmission of offending cannot stop with the assessment of the relationship between children's personalities and family bonds. In this scenario, family bonds need to be assessed within vaster and contextualised social categories that consider the osmosis between family life - including criminal families - with the local culture, because mafia clans behave within the canons of their cultural context of reference. The interaction between the local culture and its own criminal subculture needs to be fully comprehended and factored in youth justice provisions. In this scenario, child protection can become a prevention mechanism to counter the further contagion of systemic and rooted criminal (mafia-type) (sub)cultural values at the point of justifying removal from home and from the local area as ways to protect the children and prevent them from further absorbing the criminal culture. To what extent this is going to be the case in Calabria, it still needs to be assessed, but such an assessment can only be done $a$ posteriori by measuring the impact of such procedures on the children and the strength of mafia power in the region in the long term. 


\section{References}

Ahrens D. (2000) Not in front of the children: Prohibition on child custody as civil branding for criminal activity. NEw York University Law Review 75: 737-757.

Bijleveldc C, Huscheka C and Liefbroerb AC. (2016) Parental criminality and entry into parenthood among sons and daughters. Advances in Life Course Research. 28(Special issue on Criminal Careers and Demographic Outcomes: A life-course perspective): $81-90$.

Calderoni F. (2012) The structure of drug trafficking mafias: the 'Ndrangheta and cocaine. Crime, Law and Social Change 58(3): 321-349.

Calderoni F, Berlusconi G, Garofalo L, et al. (2016) The Italian mafias in the world: A systematic assessment of the mobility of criminal groups. European Journal of Criminology 13(4): 413-433.

Calderoni F and Caneppele S. (2009) La geografia criminale degli appalti: le infiltrazioni della criminalità organizzata negli appalti pubblici nel Sud Italia, Milan: Franco Angeli.

Christopher JC, Wendt DC, Marecek J, et al. (2014) Critical Cultural Awareness: Contributions to a Globalizing Psychology. The American psychologist 69(7): 645655.

Ciconte E. (2011) 'Ndrangheta, Soveria Mannelli: Rubbettino.

Cloward R and Ohlin L. (1960) Delinquency and Opportunity, New York: Free Press.

Dalla Chiesa N. (2010) La convergenza. Mafia e politica nella Seconda Repubblica Milano: Melampo.

Davidson-Arad B, Englechin-Segal D and Wozner Y. (2003) Short-term follow-up of children at risk: comparison of the quality of life of children removed from home and children remaining at home. Child Abuse \& Neglect 27(7): 733-750.

Demuth S and Brown SL. (2004) Family Structure, Family Processes, And Adolescent Delinquency: The Significance Of Parental Absence Versus Parental Gender Journal of Research in Crime and Delinquency 41(1): 58-81.

Dingwall R, Eekelaar J and Murray T. (2014) The protection of children: State intervention and family life, New Orleans: Quid Pro Books.

Dino A. (2007) Women in mafia organizations, New York: Springer.

DNA. (2017) Relazione annuale sulle attività svolte dal Procuratore nazionale e dalla

Direzione nazionale antimafia e antiterrorismo nonché sulle dinamiche e strategie della criminalità organizzata di tipo mafioso nel periodo $1^{\circ}$ luglio 2015 - 30 giugno 2016 Roma: Direzione Nazionale Antimafia e Antiterrorismo.

Farrington DP, Gundry G and West DJ. (1975) The familial transmission of criminality. . Medicine, Science and the Law 15: 177-186.

Farrington DP, Jolliffe D, Loeber R, et al. (2001) The concentration of offenders in families, and family criminality in the prediction of boys' delinquency. Journal of Adolescence 24: 579-596.

Featherstone B, White S and Morris K. (2014) Re-imagining child protection: Towards humane social work with families, Bristol: Policy Press.

Geertz C. (1973) The interpretation of cultures, New York: Basic Books.

Harding LF. (2014) Perspectives in child care policy, London: Routledge.

Harris R and Webb P. (1987) Welfare, Power and Juvenile Justice, London: Tavistok.

Ingrascì O. (2007) Women in the 'Ndrangheta: the Serraino-Di Giovine case. In: Fiandaca G (ed) Women and the Mafia. New York: Springer. 
Ingrascì O. (2011) Donne, 'ndrangheta, 'ndrine. Gli spazi femminili nelle fonti giudiziarie. Meridiana. Rivista di Storia e Scienze Sociali 67: 35-54.

Krinsky MA. (2010) Disrupting the pathway from foster care to the justice system-A former prosecutor's perspectives on reform. Family Court Review 48(2): 322-337.

Lavorgna A. (2015a) La 'ndrangheta migrante si espande a Nord Est. Giornale di Storia Contemporanea XVIII(1): 45-63.

Lavorgna A. (2015b) Organised crime goes online: realities and challenges. Journal of Money Laundering Control 18(2): 153-168.

Lindsey LL. (2016) Gender Roles: A Sociological Perspective, New York: Routledge.

Lupo S. (2011) History of the mafia, New York ; Chichester: Columbia University Press.

Mastrobuoni G and Patacchini E. (2010) Understanding Organized Crime Networks:

Evidence Based on Federal Bureau of Narcotics Secret Files on American Mafia.

Carlo Alberto Notebooks Working Papers(152).

Muncie J and Goldson BT. (2012) Youth Justice: In a Child's Best Interests? In: Simon J and Sparks R (eds) The SAGE Handbook of Punishment and Society. London: SAGE, 341-355.

Paoli L. (1994) An underestimated criminal phenomenon: the Calabrian 'Ndrangheta. European Journal of Crime, Criminal Law and Criminal Justice 3: 212-238.

Paoli L. (2003) Mafia brotherhoods : organized crime, Italian style, Oxford: Oxford University Press.

Paoli L. (2014) The Italian Mafia. In: Paoli L (ed) The Oxford Handbook of Organized Crime. New York and Oxford: Oxford University Press.

Pignatone G and Prestipino M. (2013) Cosa Nostra e 'ndrangheta: due modelli criminali. In: Ciconte E, Forgione F and Sales I (eds) Atlante delle Mafie. Storia, economia, società, cultura. Volume Secondo. Soveria Mannelli: Rubbetiino.

Piselli F and Arrighi G. (1985) Parentela, Clientela e Comunità. In: Bevilacqua P and Placanica A (eds) Storia d'Italia. Le Regioni dall'unità a oggi. La Calabria. Torino: Einaudi.

Schermi M. (2015) Criminal education: grow-up in mafia context. Italian Journal of Criminology 7(4): 256-263.

Sciarrone R. (2014a) 'Ndrangheta: A Reticular Organization. In: Serenata N (ed) The 'Ndrangheta and the Sacra Corona Unita. The History, Organization, and Operations of Two Unknown Mafia Groups. New York: Springer.

Sciarrone R. (2014b) Tra sud e nord. Le mafie nelle aree non tradizionali. In: Sciarrone R (ed) Mafie al Nord. Strategie criminali e contesti locali. Rome: Donzelli Editore.

Sergi A. (2015) Mafia and politics as concurrent governance actors. Revisiting political power and crime in Southern Italy. In: Van Duyne PC, Maljević A, Antonopoulos GA, et al. (eds) The relativity of wrongdoing: Corruption, organised crime, fraud and money laundering in perspective. Oisterwijk: Wolf Legal Publishers.

Sergi A. (2017) From Mafia to Organised Crime: a Comparative Analysis of Policing Models, London \& New York: Palgrave Macmillan.

Sergi A. (2018) What's in a name? Shifting identities of Traditional Organised Crime in Canada in the transnational fight against the Calabrian "ndrangheta. Canadian Journal of Criminology and Criminal Justice Ahead of Print DOI 10.3138/cjccj.2017-0052.r1: $1-20$.

Sergi A and Lavorgna A. (2016) 'Ndrangheta. The glocal dimensions of the most powerful Italian mafia, London, New York: Palgrave Macmillan.

Sergi P. (1991a) La 'Santa' Violenta, Cosenza: Periferia. 
Sergi P. (1991b) Storia di Domenico, bambino in fuga. La Repubblica. 11 March 1991: http://ricerca.repubblica.it/repubblica/archivio/repubblica/1991/11/03/storia-didomenico-bambino-in-fuga.html

Sergi P. (1993) Le Mie Calabrie, Soveria Mannelli: Rubbettino.

Siebert R. (2007) Mafia women: the affirmation of a female pseudo-subject, the case of the 'Ndrangheta, New York: Springer

Silverman SF. (1966) An Ethnographic Approach to Social Stratification: Prestige in a Central Italian Community. American Anthropologist 68(4): 899-921.

Sutherland E. (1947) Principles of Criminology, Philadephia: Lippincoat.

Tarsia A. (2015) Perché la 'Ndrangheta? Antropologia dei calabresi, Roma: Pungitopo.

Todini P. (2015) Tutela dei minori di mafia attraverso i provvedimenti de potestate. Nuove Frontiere del Diritto http://www.nuovefrontierediritto.it/tutela-dei-minori-di-mafiaattraverso-i-provvdimenti-de-potestate/

Travaglino GA, Abrams D and de Moura GR. (2016) Men of Honor Don't Talk: The Relationship Between Masculine Honor and Social Activism Against Criminal Organizations in Italy. Political Psychology 37(2): 183-199.

Varese F. (2005) How mafias migrate : the case of the 'Ndrangheta in northern Italy, Oxford: University of Oxford.

Varese F. (2011) Mafias on the move : how organized crime conquers new territories, Princeton, N.J. ; Oxford: Princeton University Press.

Von Lampe K. (2016) Organized Crime. Analyzing Illegal Activities, Criminal Structures, and Extra-legal Governance, New York: SAGE.

Wilson H. (1987) Parental supervision re-examined. British Journal of Criminology 27: 275301.

Zaitchik MC and Mosher DL. (1993) Criminal Justice Implications of the Macho Personality Constellation. Criminal Justice and Behavior 20(3): 227-239. 